\title{
Pengembangan Media Pembelajaran Permainan Ludo Pada Materi Operasi Pengurangan Kelas 3 MIS Sindangraja
}

\author{
Agit Darojatil Izzaty $^{1}$ Sunanih $^{2}$, Meiliana Nurfitriani ${ }^{3}$ \\ 123Pendidikan Guru Sekolah Dasar Universitas Muhammadiyah Tasikmalaya, Indonesia \\ 1․gitdarojatilizzaty@gmail.com, 2Sunanih@umtas.ac.id, $\underline{\text { 3Meiliana.nurfitriani@umtas.ac.id }}$
}

\begin{tabular}{|c|c|}
\hline Informasi Artikel & Abstrak \\
\hline $\begin{array}{l}\text { Kata kunci: } \\
\text { Research and } \\
\text { development, } \\
\text { permainan ludo, } \\
\text { media, } \\
\text { operasi } \\
\text { pengurangan. }\end{array}$ & $\begin{array}{l}\text { Penelitian dan pengembangan ini dilatarbelakangi oleh adanya potensi dan } \\
\text { masalah, potensi pada penelitian ini mengenai beberapa media pembelajaran } \\
\text { yang dapat merangsang atau memmudahkan proses pembelajaran. Sedangkan } \\
\text { pada masalahnya yaitu siswa kurang memmahami operasi pengurangan sehingga } \\
\text { harus menjelaskan materi tersebut secara berulang-ulang, hal ini dikarenakan } \\
\text { tidak ada rangsangan untuk mendukung proses pembelajaran. Hal ini dapat } \\
\text { dibuktikan dengan nilai rata-rata } 70 \text {, dan nilai KKM pada mata pelajaran tersebut } \\
\text { 75. Sehingga dapat disimpulkan nilai rata-rata tersebut kurang dari nilai KKM. } \\
\text { Oleh sebab itu diperlukan media pembelajaran berlandaskan potensi dan } \\
\text { masalah tersebut. Sehingga dibuatlah media pembelajaran permainan ludo pada } \\
\text { operasi pengurangan kelas } 3 \text { MIS Sindangraja. Penelitian ini termasuk ke dalam } \\
\text { jenis dan desain penelitian pengembangan atau R\&D (Research and Development) } \\
\text { tipe Borg and Gall dilakukan di Sekolah MIS Sindangraja dengan jumlah } 16 \\
\text { siswa. Teknik pengumpulan data dilakukan dengan tes prestest dan postest. } \\
\text { Data dianalisis dengan SPSS. }\end{array}$ \\
\hline Disetujui: & Abstact \\
\hline Dipubikasikan: & $\begin{array}{l}\text { This research and development is motivated by the existence of potentials and } \\
\text { problems, the potential in this study regarding several learning media that can } \\
\text { stimulate or facilitate the learning process. Whereas the problem is that students } \\
\text { do not understand the subtraction operation so they have to explain the material } \\
\text { repeatedly, this is because there is no stimulus to support the learning process. } \\
\text { This can be proven by the average value of } 70 \text {, and the KKM score in these } \\
\text { subjects } 75 \text {. So it can be concluded that the average score is less than the KKM } \\
\text { value. Therefore, a learning media is needed based on these potentials and } \\
\text { problems. So that ludo game learning media was created in the MIS Sindangraja } \\
\text { class } 3 \text { reduction operation. This research is included in the type and design of } \\
\text { research development or R\&D (Research and Development) of the Borg and } \\
\text { Gall type which was carried out at the Sindangraja MIS School with a total of } \\
16 \text { students. The data collection technique was done by using prestest and } \\
\text { postest tests. Data were analyzed by SPSS. }\end{array}$ \\
\hline
\end{tabular}




\section{PENDAHULUAN}

Pembelajaran matematika diberikan kepada siswa disetiap jenjang pendidikan yang mempunyai peranan penting dalam proses berpikir siswa. Selain itu, matematika juga dapat menjadi bekal dalam kehidupan sehari-hari contoh dalam proses jual beli terdapat mata pelajaran matematika. Susanto (2016:183) menyatakan bahwa "matematika merupakan ide-ide abstrak yang berisi simbol-simbol dan terlebih dahulu harus memahami konsep sebelum memanipulasi simbol-simbol". Maka dari itu, matematika merupakan bidang studi yang harus dikuasai dengan baik oleh peserta didik terutama dimulai sejak usia sekolah dasar.

Belajar operasi hitung mulai diterapkan kepada anak ketika memasuki Sekolah Dasar. Operasi hitung yang dimaksud adalah penjumlahan, pengurangan, perkalian dan pembagian. Operasi hitung bilangan ini sudah diterapkan kepada anak sekolah dasar kelas 3 terutama operasi pertambahan dan pengurangan. Namun dalam penerapannya, siswa cenderung merasa kesulitan dalam mengoprasikannya. Hal ini dibuktikan dengan perbedaan waktu dalam pengerjaan soal antara pertambahan dan pengurangan.

Berdasarkan wawancara kepada kepala sekolah dan wali kelas 3 MIS Sindangraja bahwasannya belajar operasi hitung juga memiliki hambatan-hambatan dalam proses pembelajaran berlangsung yaitu kurangnya media untuk mendukung proses pembelajaran sehingga peserta didik merasakan kesulitan pada materi operasi pengurangan. Sehingga nilai rata-rata peserta didik dari 16 orang pada materi tersebut hanya mencapai 70 yang berarti kurang 5 dari nilai KKM pelajaran matematika yaiu 75. Maka dari itu dalam proses pembelajaran perlu adanya media pembelajaran.

Media merupakan segala bentuk dan saluran penyampaian pesan/ informasi dari sumber pesan ke penerima atau dari guru ke siswa sehingga siswa mampu memperoleh pengetahuan, keterampilan atau sikap yang sesuai dengan tujuan informasi yang disampaikan guru (Suryani, 2018: 2). Sehingga adanya media dalam proses pembelajaran akan sangat membantu proses pem belajaran.

Dari uraian tersebut media pembelajaran memiliki peran yang sangat penting dalam proses pembelajaran berlangsung. Dari sekian jenis pembelajaran ada satu media pembelajaran permainan yang menarik untuk diterapkan dalam proses pembelajaran terutama pada materi operasi pengurangan yaitu permainan ludo. Ludo merupakan permainan yang dapat digunakan secara berkelompok sehingga dapat dijadikan media pembelajaran karena merupakan salahsatu sarana proses belajar mengajar. Penggunaaan permainan dalam pembelajaran dapat mengembangkan kemampuan peserta didik. Sehingga dapat mempermudah guru untuk merangsang peserta didik untuk belajar. Permainan ludo ini dipilih karena dalam permainan ini seluruh peserta didik terlibat aktif dalam proses pembelajaran. Permainan ludo ini telah dimodifikasi pada komponen-komponen permainan ludo sesuai dengan kebutuhan peserta didik.

Adanya media pembelajaran ini diharapkan mampu merangsang minat siswa untuk mempelajari operasi pengurangan. Maka dari itu pada penelitian ini peneliti akan memfokuskan pada pengembangan media pembelajaran permainan ludo pada materi operasi pengurangan kelas 3 di MIS Sindangraja. 


\section{METODE}

Penelitian ini menggunakan pendekatan R\&D (Research and Development). Penelitian R\&D adalah aktivitas riset dasar untuk mendapatkan informasi kebutuhan pengguna (needs assessment), kemudian dilanjutkan kegiatan pengembangan (development) untuk menghasilkan produk dan menguji keefektifan produk tersebut. Dalam penelitian ini menggunakan pendekatan R\&D karena dalam penelitian ini akan menghasilkan produk yang berupa media pembelajaran Ludo Matematika untuk operasi pengurangan. Borg and Gall mengungkapkan ada 10 langkah dalam proses penelitian pengembangan, Berikut ini adalah langkah-langkah model penelitian pengembangan dari Sugiyono (2016: 409) yang digunakan oleh peneliti :

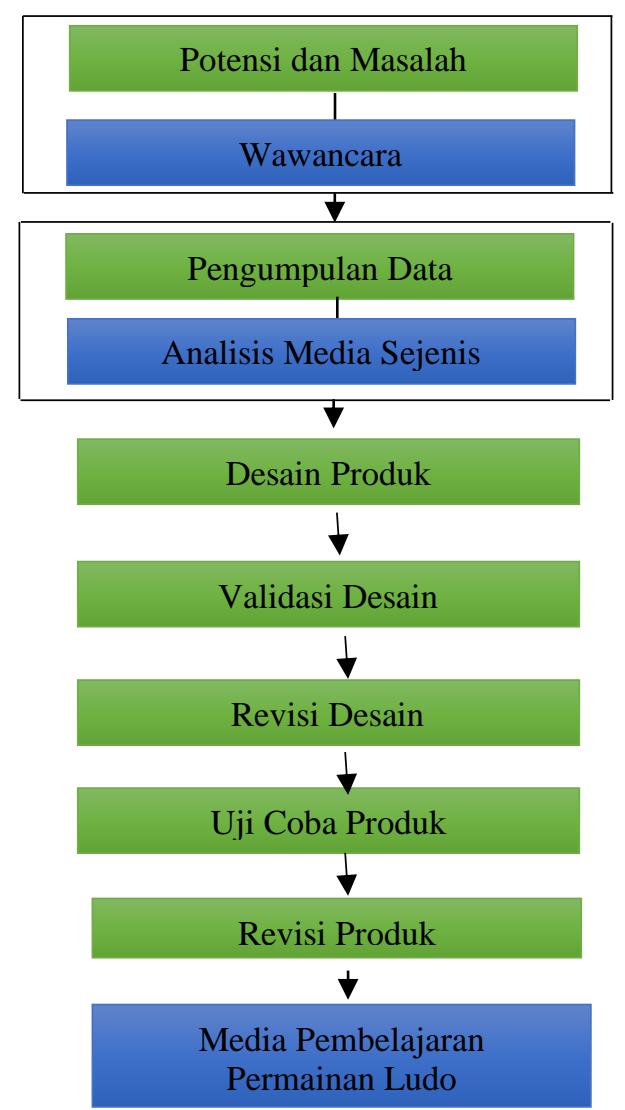

Gambar 1. Langkah-langkah penelitian R\&D Adaptasi Sugiyono

Penelitian dilaksanakan MIS Sindangraja yang berlokasi di Kp. Sindangraja Desa Linggawangi Kec. Leuwisari. Waktu penelitian dilaksanakan pada bulan Oktober 2020. Subyek penelitian pada penelitian pengembangan ini terdiri dari ahli media, ahli materi, sebelum dilakukan metode pembelajaran siswa diberikan soal pretest terlebih dahulu dan kemudian diberikan soal post test kepada siswa sebagai bentuk perbandingan dari sebelum dan sesudah menggunakan media pembelajaran.

Teknik pengumpulan data yang digunakan dalam penelitian ini yaitu dengan observasi, wawancara dan angket. Observasi dilakukan saat akan dilaksanakannya penelitian untuk memperoleh data sebagai sebuah dasar dilaksanakannya penelitian dan pengembangan. Wawancara dilaksanakan dengan wali kelas III MIS Sindangraja dan siswa untuk memperoleh data mengenai kebutuhan dalam penelitian dan 
pengembangan. Angket digunakan untuk memperoleh data penilaian kualitas kelayakan media yang dikembangkan menurut ahli media, ahli materi dan siswa pada ujicoba lapangan.

\section{HASIL DAN PEMBAHASAN}

Potensi dan masalah yang terdapat di MIS Sindangraja pada mata pelajaran matematika kelas III yaitu mengenai pengurangan. Berdasarkan hasil wawancara dengan guru kelas III MIS Sindangraja yaitu bu Nina Erniawati, permasalahan yang terjadi pada pembelajaran operasi pengurangan di kelas III yaitu siswa kurang memahami konsep operasi pengurangan, nilai rata-rata kurang dari nilai KKM, minimnya penggunaan media pembelajaran dalam pembelajaran matematika di MIS Sindangraja, respon siswa pada saat proses pembelajaran ada yang masih belum aktif dalam mengikuti pembelajaran, Metode pembelajaran yang digunakan guru hanya ceramah sehingga membuat siswa tidak bersemangat dalam belajar. Berdasarkan permasalahan yang ditemui dilapangan, maka penulis tertarik untuk mengembangkan media pembelajaran yang dapat membantu siswa dalam memahami materi operasi pengurangan. Pembelajaran permainan ludo juga dapat membuat siswa lebih aktif dan menyenangkan dalam proses pembelajaran.

Pada tahap desain produk, langkah yang harus dillakukan yaitu membuat story board media pembelajaran:

\begin{tabular}{|l|l|l|l|}
\hline No. & \multicolumn{2}{|c|}{ Sketsa } & \multicolumn{1}{|c|}{ Keterangan } \\
\hline 1. & & $\begin{array}{l}\text { Papan bagian utama terdapat sebuah nama yang } \\
\text { menggambarkan papan permaianan secara utuh. } \\
\text { Desain tulisan dan background dibuat untuk } \\
\text { mencerminkan papan permainan ludo } \\
\text { matematika. }\end{array}$ \\
\hline 2. & & \\
\hline
\end{tabular}




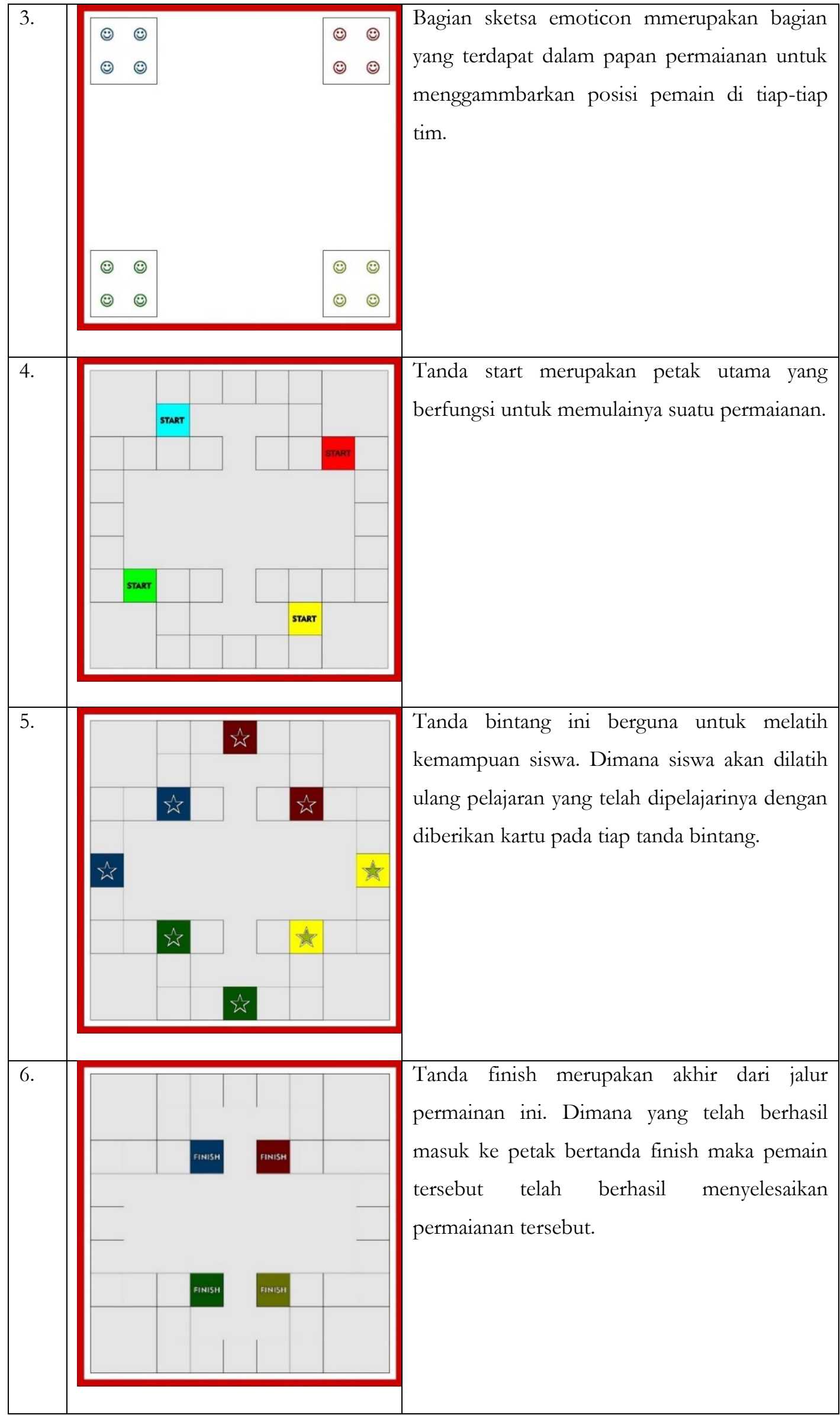




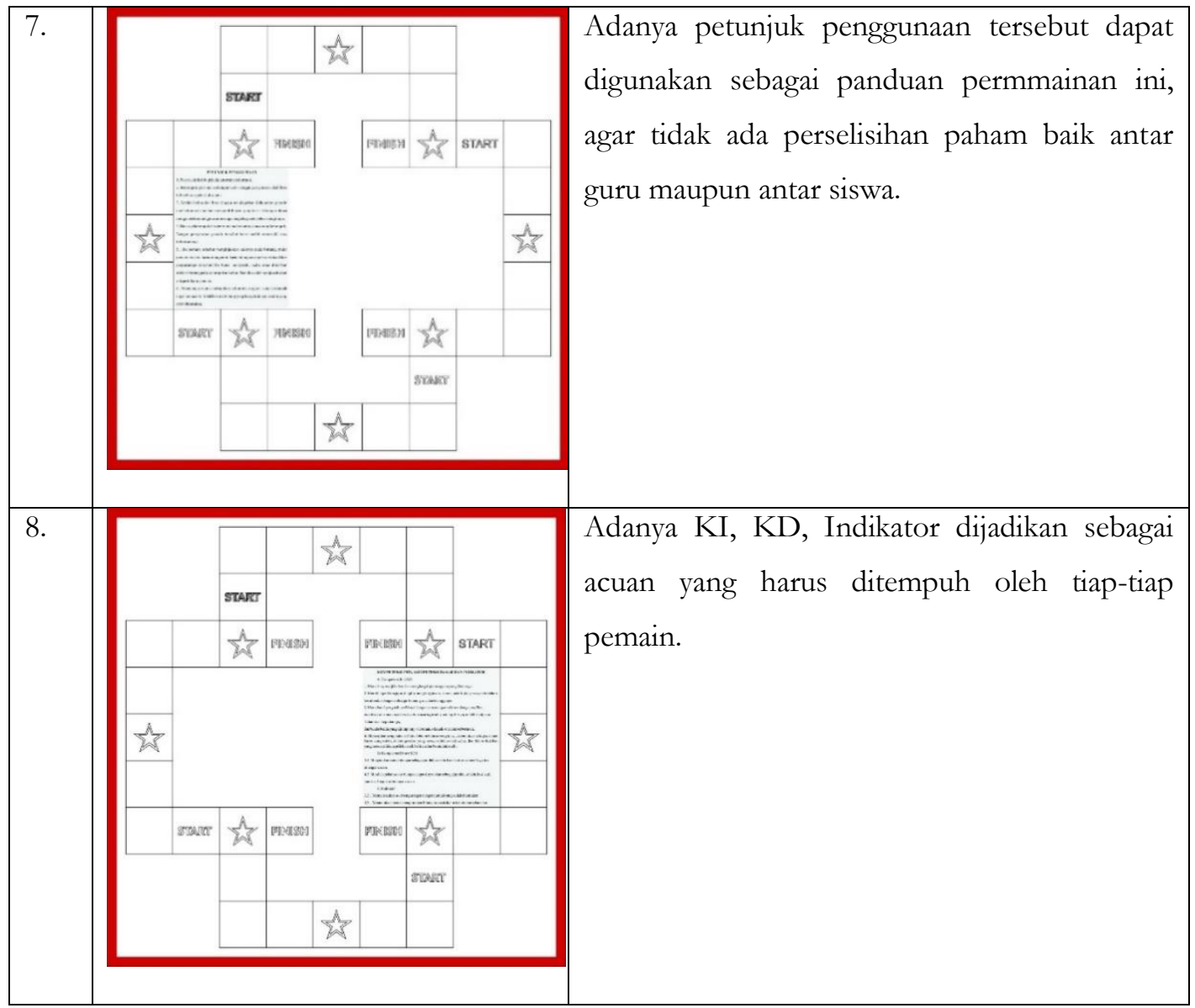

Adapaun validasi desain dilakukan sebelum proses penelitian berlangsung. Berdasarkan validasi ahli materi pada tahap ini hanya melipti aspek isi yang meliputi materi yang disampaikan sesuai dengan kurikulum 2013, media pembelajaran permainan ludo dapat mendukung pencapaian kopetensi dasar dan indikator, materi yang disampaikan sesuai dengan tujuan pembelajaran dan media pembelajaran permainan ludo dapat memudahkan siswa untuk memahami materi tersebut. Sehingga rata-rata total skor yang diperoleh dari rekapitulasi hasil validasi ahli materi yaitu 4,5 dengan kategoori "Sangat Baik" sehingga media pembelajaran permainan ludo layak digunakan uji coba. Hasil validasi ahli media secara keseluruhan meliputi aspek aspek efesiensi alat, ketahanan alat, estetika atau tampilan, keamanan alat peraga.memperoleh ratarata total skor 4,1 dengan kategori "Baik" sehingga media pembelajaran permainan ludo layak untuk diuji coba. Berdasarkan validasi guru secara keseluruhan meliputi aspek isi dan keakuratan alat peraga memperoleh rata-rata total skor 4,5 dengan kategori "sangat baik" sehingga media pembelajaran permainan ludo layak untuk di uji coba. Sedangkan berdasarkan validasi siswa secara keseluruhan meliputi aspek isi dan keakuratan alat peraga memperoleh rata-rata total skor 4,5 dengan kategori "sangat baik" sehingga media pembelajaran permainan ludo layak untuk di uji coba.

Berdasarkan hasil validasi yang dilakukan oleh ahli materi, ahli media dan guru, desain dari permainan ludo ini mengasilkan perubahan yaitu menambahkan kompetensi inti, kompetensi dasar, indikator dan petunjuk penggunaan. Perubahan media permainan ludo ini sebagai berikut: 


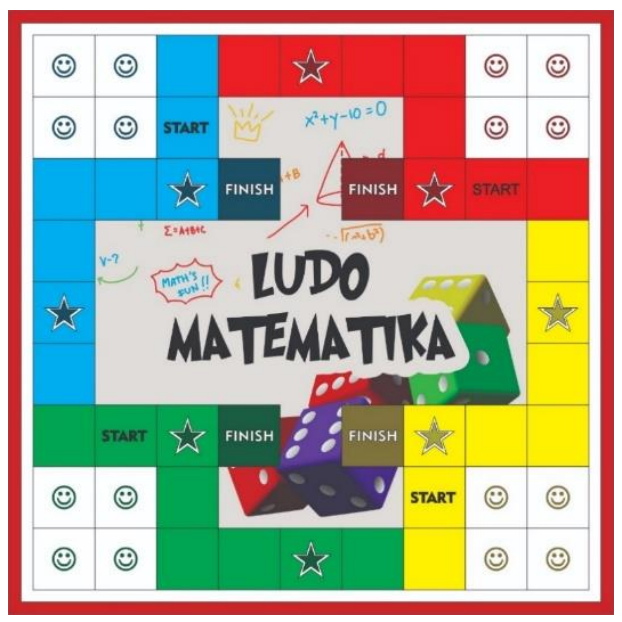

Gambar 2. Papan media pembelajaran permainan ludo sebelum revisi

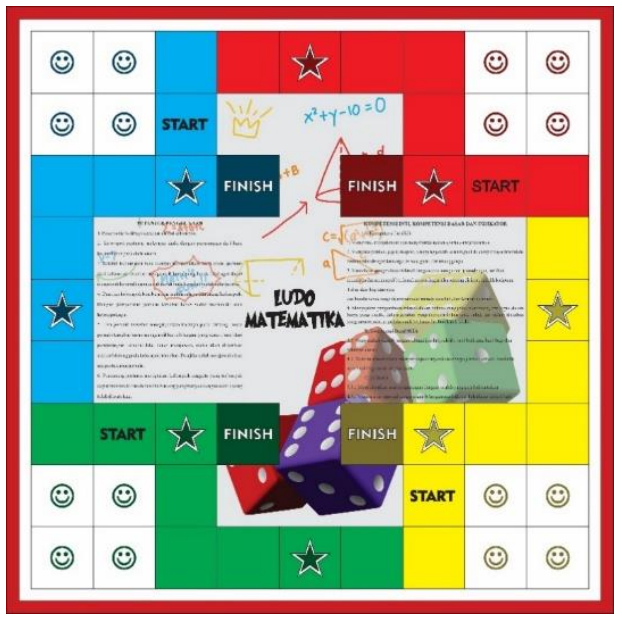

Gambar 3. Papan media pembelajaran permainan ludo masih terdapat revisi

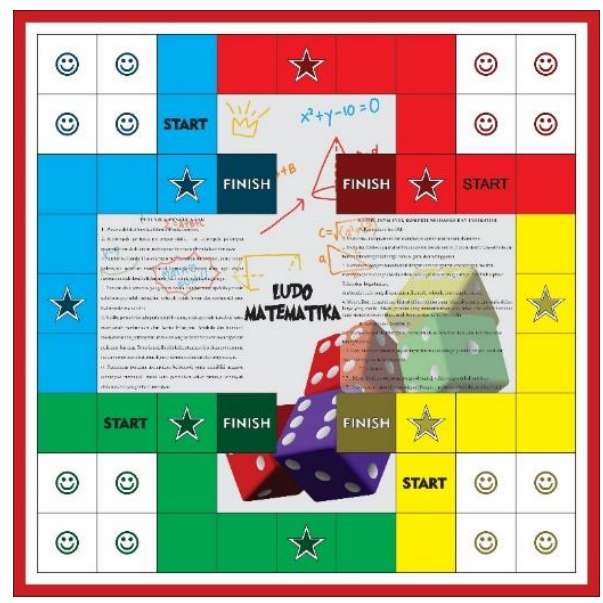

Gambar 4. Papan media pembelajaran permainan ludo setelah revisi

Setelah dilakukan validasi dan perbaikan revisi maka selanjutnya dilakukan uji coba produk dengan menggunakan soal pretest dan soal postest. Berdasarkan uji validitas dari keseluruhan soal pretest dan soal pretest sebanyak 10 butir soal. Terdapat 1 soal yang tidak valid yaitu pada butir soal nomor 6. Sehingga dapat digunakan sebagai soal test untuk mengukur kemampuan siswa pada materi operasi pengurangan karena 
soal tersebut sudah dilakukan validitas isi kepada ahli (expert judgment) dan hasilnya sudah valid. Sedangkan hasil realibilitas pada tabel 15 soal pretest dan postest dinyatakan sudal reliabel. Hasil Cronbach's Alpha pada soal pretest dan postest yaitu 0,472. Artinya nilai 0,427 >0,291 sehingga dari 15 butir soal pretest dan postest dikatakan reliabel.

Berdasarkan hasil analisis uji coba satu-satu maka secara keseluruhan memperoleh rata-rata 4 dengan kategoori "Baik" dan tidak terdapat saran dan masukkan sebagai bahan perbaikan pada uji coba satu-satu bahwa belajar menggunakan media pembelajaran permainan ludo mudah dipahami, membantu dalam proses pembelajaran, dapat menciptakan pembelajaran yang menyenangkan. Adapun dilihat dari segi tampilannya, media permainan ludo sangat menarik. Kemudian berdasarkan hasil analisis data uji coba kelompok kecil, maka secara keseluruhan memperoleh hasil 4,125 dengan kategori "Baik" dan tidak terdapat saran dan masukkan sebagai bahan perbaikan pada uji coba kelompook kecil. Ulasan mereka dengan adanya media ini siswa lebih semangat untuk belajar karena pembelajaran yang tidak menjenuhkan seingga siswa bersemangat untuk belajar. Selain itu dilihat dari aspek penampillan media ini sangat menarik, warna yang digunakan pada media terlihhat kontras dan jelas. Dengan demikian dalam hal ini, media pembelajaran permainan ludo berdasarkan hasil uji kelompok kecil layak dan efektif untuk untuk dijadikan media pembelajaran pada materi operasi pengurangan dalam mata pelajaran Matematika. Sedangkan Berdasarkan hasil analisis data uji coba kelompok besar, maka secara keseluruhan memperoleh hasil 4,125 dengan kategori "Baik" dan tidak terdapat saran dan masukkan sebagai bahan perbaikan pada uji coba kelompok besar. Pendapat mereka tentang adanya media ini akan membuat siswa lebih bersemangat untuk belajar karena pembelajaran yang menyenangkan. Selain itu penampilan pada media ini juga sangat menarik, warna yang digunakan pada media terlihhat kontras dan jelas. Gambar, tulisan, angka juga terlihat begitu jelas. Dengan demikian media berdasarkan hasil uji kelompok besar layak dan efektif untuk untuk dijadikan media pembelajaran pada materi operasi pengurangan dalam mata pelajaran Matematika kelas III.

Setelah melakukan uji kelompok besar, selanjutnya diberikan soal postest yang bertujuan mengukur kemampuan siswa pada materi operasi pengurangan. Hasil yang diperoleh menunjukkan bahwa rata-rata nilai (pretest adalah 72,5, dan rata-rata nilai postest adalah 85 . Hal ini menunjukkan bahwa nilai postest lebih tinggi dari pada nilai pretest. Nilai kualitas tingkat keefektifan media secara keseluruhan yaitu memepeoleh nilai 0,35 dengan kategori "Sedang". Setelah itu, nilai pretest dan postest akan dianalisis dengan uji paired sampel T-Test dengan taraf signifikasi 0,05 . Sedangkan berdasarkan hasil uji paired sampel T-Test menunjukkan bahwa T-Hitung adalah 3.596 dengan df 15, sehingga menunjukkan T-Tabel 2,131 dengan taraf signifikan 0,05, maka T-Hitung > T-Tabel atau 3,596 > 2,131. Maka, dapat disimpulkan bahwa Ho ditolak Ha diterima artinya terdapat perbedaan yang signifikan antara sebelum dan sesudah menggunakan media pembelajaran permainan ludo pada operasi pengurangan di MIS Sindangraja. Dilihat dari hasil ratarata nilai postest 85 sudah berada diatas nilai Kriteria Kelulusan Minimal (KKM) pada mata pelajaran Matematika yaitu sebesar 75. Maka media pembelajaran permainan ludo dapat dikatakan layak dan efektif untuk digunakan pada mata pelajaran operasi pengurangan. Berdasarkan hasil rata-rata nilai postest 85 lebih 
besar dari nilai pretest 72,5. Maka dapat disimpulkan bahwa media pembelajaran permainan ludo dapat dikatakan layak dan efektif untuk digunakan pada mata pelajaran Matematika materi operasi pengurangan.

\section{KESIMPULAN}

Pengembangan media pembelajaran permainan ludo layak digunakan dalam pemmbelajaran. Kelayakan produk berdasarkan penilaian ahli materi dan ahli media dengan penilaian presentase rata-rata 4,5 dalam kategori sangat baik dan 4.1 dalam kategori baik. Hasil uji coba yang dilakukan yaitu sebanyak 3 kali yaitu uji coba satu-satu dengan siswa sebanyak 4 orang, uji coba kelompok kecil dengan siswa sebanyak 8 orang, dan uji kelompok besar dengan siswa sebanyak 16 orang. Dan diperoleh nilai pretest 72,5 dan postest 85 . Hal ini menunjukkan bahwa nilai postest lebih tinggi dari pada nilai pretest.

\section{DAFTAR PUSTAKA}

Ananda, Rizki. 2017. Peningkatan Hasil Belajar Siswa pada Materi Operasi Pengurangan Bilangan Cacah dengan Menggunakan Blok Dienes Siswa Kelas I SDN 016 Bangkinang Kota. Jurnal Pendidikan Matematika. Vol. 1, No. 1, Mei 2017. 1-11

Arsyad, Azhar. 2019. Media Pembelajaran. Depok: PT. Raja Grafindo Persada.

DIKNAS. 2018, Tema 4- Kewajiban dan Hakku. Kementrian Pendidikan dan Kebudayaan.

Jalinus, Nizwardi \& Ambiyar. 2016. Media \& Sumber Pembelajaran. Jakarta: Kencana.

Miftah, M. 2013. Fungsi dan Peran Media Pembelajaran Sebagai Upaya Peningkatan Kemampuan Belajar Siswa. Jurnal Kwangsan. Vol. 1 - Nomor 2, 100.

Nurlela, Siti K. 2019. Pengembangan Media Pembelajaran Layang-layang Bilangan pada Konsep Nilai Tempat Bilangan di SDN 2 Singaparna. Skripsi. Tidak diterbitkan, Universitas Muhammadiyah Tasikmalaya.

Sugiyono. 2017. Metode Penelitian Kuantitatif, Kualitatif dan R\&D. Bandung: Alfabeta

Sunaengsih, Cucun. 2016. "Pengaruh media pembelajaran terhadap mutu pembelajaran pada sekolah dasar terakreditasi A". Mimbar Sekolah Dasar, Vol 3(2) 2016, 183-190.

Suryani, Nunuk, acghmad Setiawan, dkk. 2018. Media Pembelajaran Inovatif dan Pengembangannya. Bandung: PT Remaja Rosdakarya.

Susilana, Rudi, Cepi Riyana. 2017. Media Pembelajaran. Bandung: CV Wacana Prima.

Widoyoko, E.P. 2015. Evaluasi program pembelajaran. Yogyakarta: Pustaka Pelajar.

Rahmaati, Nurina Kusuma (2018). Efektifitas Penerapan Metode Drill Dan Metode Resitasi Terhadap Hasil Belajar Matematika Pada Materi Aritmatika Sosial buana Pendidikan: Jurnal Fakultas Keguruan Dan Ilmu Pendidikan 14(25). 59-64 http://jurnal.unipasby.ac.id/index.php/jurnal buana pendidikan/index

Lestari, Ila, ddk (2019). Korelasi Antara Kemandirian Dengan Hasil Belajar Matematika Pada Peserta Didik. Buana Pendidikan: Jurnal Fakultas Keguruan Dan Ilmu Pendidikan. 15(26). 118-127. http://jurnal.unipasby.ac.id/index.php/jurnal buana pendidikan/index

Kusniati, Tri (2020).Meningkatkan Hasil Belajar Operasi Hitung Bilangan Pecahan Dengan Kartu Bilngan Siswa Kelas VI SDN 3 Mangliawan Kecamatan Pakis Kabupaten Malang. Buana Pendidikan: Jurnal Fakultas Keguruan Dan Ilmu Pendidikan. 16(29). 52-64.

http://jurnal.unipasby.ac.id/index.php/jurnal buana pendidikan/index 